\title{
Organic matter digestibility in horses and its prediction
}

\author{
E. A. A. SMOLDERS 1 , A. STEG ${ }^{2} \&$ V. A. HINDLE 2 \\ 1 Research Station for Cattle, Sheep and Horse Husbandry, Runderweg 6, NL 8219 PK \\ Lelystad, Netherlands \\ 2 Research Institute for Livestock Feeding and Nutrition, P.O. Box 160, NL 8200 AD \\ Lelystad, Netherlands
}

Received 22 February 1990; accepted 1 May 1990

\begin{abstract}
Organic matter (OM) digestibility of 53 feedstuffs was determined in horses, sheep and in invitro using rumen fluid. Feeds tested were: roughages (grass hay, fresh grass, wilted grass silage, forage maize and artificially dried roughage), compound feeds and compound feed ingredients including cereals. Technical merits of the chosen procedure for execution of digestibility trials with horses are discussed. Horse digestibility data for forages were consistently lower than sheep data, with a variable fibre level effect. For compound feeds and compound feed ingredients horse digestibility was on average comparable to sheep digestibility allowing for considerable differences between feeds. The in vitro digestibility with rumen fluid offers a reliable estimation of OM digestibility in horses for the different groups of feeds.
\end{abstract}

Keywords: horses, digestibility, organic matter, predictions, equations

\section{Introduction}

At present there is no specific feed evaluation system for horses in use in the Netherlands. Feed evaluation for horses is performed using the feed evaluation system for ruminants, although important differences have been observed concerning the magnitude and the process of digestion between horses and ruminants because of a different compartmentation in the digestive tract. Therefore the apparent digestibility of feedstuffs may differ considerably from ruminant data. Several authors (Martin-Rosset \& Dulphy, 1987; Hofmann et al., 1987; Udén \& van Soest, 1982) indicate occassional large differences in OM digestibility between horses and ruminants depending on the chemical composition of the feedstuffs, especially for fibrous feeds. However, information concerning high-energy feeds (good-quality roughage, compound feed ingredients), especially in comparison to wethers is scarce. To improve the energy evaluation of these types of feed it was considered necessary to obtain more information on their digestibility in the horse. Between August 1984 and May 1989, 53 digestibility trials were performed in a co-operative 
study between the Research Institute for Livestock Feeding and Nutrition (IVVO) and the Research Station for Cattle, Sheep and Horse Husbandry (PR) in Lelystad. Comparative studies were performed in which 21 feed samples were compared with sheep, 9 with ponies and 13 with pigs. Relationships in digestibility between sheep and horses were examined in order to establish a more correct feed evaluation for horses adopting the current systems of evaluation for ruminants. This report presents the data obtained relevant to organic matter digestibility in horses and sheep.

\section{Materials and methods}

\section{Animals}

For the horse trials 8 saddle horse geldings were available. Live bodyweight of the horses in the experiments was $519 \pm 29 \mathrm{~kg}$ and their age varied from 3 to 13 years. The 36 wethers used in the digestibility trials weighed $77 \pm 10 \mathrm{~kg}$ and ranged in age from 22 to 65 months.

The horses were fed at approximately maintenance requirement for energy. For practical reasons the feed allowance was restricted on the basis of dry matter intake: all rations were fed at $50 \mathrm{~g}$ dry matter (DM) per $\mathrm{kg}$. The horses were weighed at the start of the adaptation period and at the beginning and end of the faeces collection period. During periods in which compound feed ingredients were tested, the ration for the horses between two digestibility trials was supplemented with a mineral/vitamin mixture as prevention against deficiencies. Drinking water was supplied ad libitum.

During the experimental period of 21 days the horses were housed in metal cages $60 \mathrm{~cm}$ wide and $250 \mathrm{~cm}$ long. The animals were unable to lay down. At the front of the cage two feeding boxes were attached and at the side an automatic drinking bowl. Both sides of the cages were covered to a height of $190 \mathrm{~cm}$ with rubber mats. Behind the animals a steel bar was attached. The front part of the cages had a closed wooden floor, the hind part a steel slatted floor through which the faeces could drop into a plastic collection box beneath. No harnasses were needed. The horses were exercised for half an hour each day on a rotary exerciser. Before exercise the rectum of the horses was emptied manually. During exercise the horses were under continual supervision so that no faeces were lost.

The experiments with wethers were carried out according to the methods described by van Es \& van der Meer (1980). The daily allowance for these animals was standardized at approximately $1000 \mathrm{~g} \mathrm{DM}$.

\section{Trials}

The experiments with wethers and horses fed roughage and compound feeds were performed with 4 animals per experiment. The experiments with horses fed concentrates (compound feed ingredients) were performed with only two animals per trial.

Prior to the experiments with compound feed ingredients the feed to be examined 
was presented to the animals in order to ascertain its palatability for horses. In this way an attempt was made to keep to a minimum disturbances caused by food refusals during the trials.

The composition of the rations was similar for both horses and sheep. The roughages were fed as sole feed. In experiments with compound feeds and compound feed ingredients $70 \%$ of the DM was given as experimental feed supplemented with $30 \%$ as roughage (grass hay) to avoid vices. Whole ground soya beans were also tested at $50 \%$ as well as $30 \%$ of the total ration. The digestibility of the roughage supplement was determined twice with horses; prior to and after completion of a trial series.

For both horses and sheep each experimental period lasted 21 days; an adaptation period of 11 days followed by a 10-day faeces collection period.

Daily feed portions were weighed before the trials started and stored in plastic bags. Feeds with a high moisture content (fresh grass and silages) were stored at $-20{ }^{\circ} \mathrm{C}$ and defrosted $24 \mathrm{~h}$ prior to feeding. The animals were fed twice daily at approx. 9:00 $\mathrm{h}$ and 16:30 $\mathrm{h}$.

\section{Analytical methods}

All test feeds were sampled in triplicate and presented to the IVVO laboratory for proximate analysis. Supplementary feeds were sampled in duplicate. The faeces were collected twice daily after each feeding in large plastic boxes and stored at $-20^{\circ} \mathrm{C}$. After completion of each trial the faeces were defrosted, mixed thoroughly and two sub-samples were taken for proximate analysis.

Chemical analyses procedures were performed according to IVVO standard analytical procedures (Steg et al., 1990).

\section{Statistical analysis}

Statistical analyses of the digestibility data obtained included single and multiple linear regression for prediction of apparent digestibility of feeds in horses from sheep data and laboratory analyses using the statistical package Genstat (Alvey et al., 1980). Experiments resulting in large between-horse differences for OM digestibility $(>3.0)$ in trials performed with only two horses were excluded from further analysis.

\section{Feedstuffs tested}

Table 1 gives an indication of the chemical composition of the feeds examined. The group numbers refer to a classification of available feedstuffs (CVB, 1977). The grass hays (Group 1) and wilted grass silages (Group 2) consisted generally of perennial ryegrass fertilized at approximately $350 \mathrm{~kg} \mathrm{~N}^{-1} \mathrm{yr}^{-1}$. Hay 11 was second cut and was wilted for 4 days, Hays 12 and 19 were second cut and wilted for 2 days after which they were artificially dried for 2 days using forced air ventilation in a barn. Hays 14 and 15 were first cut and wilted for a period of 10 days. Hay 16 was 
Table 1. Characteristics of the feeds studied.

\begin{tabular}{|c|c|c|c|c|c|c|c|c|c|c|c|}
\hline Group & Feed & Name & $\mathrm{OM}^{\mathrm{t}}$ & $\mathrm{CP}$ & CFA & $\mathrm{CF}$ & NDF & GE & $\mathrm{d}_{\mathrm{OMh}}$ & $\mathrm{H}$ & $S$ \\
\hline 1 & 11 & Grass hay $3500 \mathrm{~kg} \mathrm{DM}$ & 866 & 175 & 21 & 283 & 549 & 18.6 & 57.7 & 4 & 4 \\
\hline 1 & 12 & Grass hay $3500 \mathrm{~kg} \mathrm{DM}$ & 905 & 184 & 32 & 257 & 546 & 18.6 & 64.9 & 7 & 4 \\
\hline 1 & 14 & Grass hay $4500 \mathrm{~kg}$ DM & 924 & 160 & 19 & 355 & 695 & 18.9 & 54.9 & 8 & 4 \\
\hline 1 & 15 & Grass hay $6000 \mathrm{~kg} \mathrm{DM}$ & 903 & 122 & 16 & 352 & 679 & 17.9 & 45.7 & 4 & 3 \\
\hline 1 & 16 & Grass hay $4500 \mathrm{~kg} \mathrm{DM}$ & 866 & 171 & 14 & 315 & 614 & 18.3 & 62.3 & 4 & 4 \\
\hline 1 & 17 & Grass seed straw & 900 & 83 & 10 & 394 & 709 & 18.0 & 33.3 & 4 & 4 \\
\hline 1 & 19 & Grass hay $3500 \mathrm{~kg} \mathrm{DM}$ & 916 & 137 & 17 & 333 & 628 & 18.3 & 59.1 & 6 & - \\
\hline 2 & 35 & Grass silage & 874 & 192 & 37 & 275 & 569 & 18.2 & 64.6 & 4 & - \\
\hline 2 & 36 & Grass silage & 886 & 182 & 36 & 228 & 474 & 18.5 & 69.1 & 4 & - \\
\hline 2 & 37 & Grass silage & 875 & 206 & 34 & 231 & 450 & 19.1 & 74.9 & 4 & - \\
\hline 2 & 38 & Grass silage & 865 & 184 & 46 & 244 & 445 & 18.2 & 73.2 & 4 & - \\
\hline 2 & 39 & Grass silage & 859 & 206 & 38 & 216 & 403 & 18.5 & 74.6 & 4 & - \\
\hline 3 & 54 & Fresh grass & 896 & 139 & 39 & 232 & 450 & 18.2 & 72.7 & 4 & 4 \\
\hline 3 & 55 & Fresh grass & 897 & 144 & 35 & 244 & 491 & 18.1 & 71.5 & 4 & 3 \\
\hline 4 & 41 & Maize silage & 941 & 90 & 27 & 206 & 425 & 18.7 & 70.1 & 4 & - \\
\hline 5 & 71 & Dehydrated grass & 829 & 197 & 32 & 247 & 500 & 16.9 & 60.1 & 4 & 4 \\
\hline 5 & 72 & Dehydr. grass meal & 894 & 149 & 32 & 292 & 554 & 18.5 & 58.2 & 2 & $4^{*}$ \\
\hline 5 & 721 & Dehydr. grass meal & 795 & 140 & 22 & 284 & 465 & 16.0 & 58.4 & $2 *$ & - \\
\hline 5 & 609 & Dehydr. lucerne meal & 888 & 176 & 22 & 365 & 543 & 18.6 & 47.0 & 2 & 4 \\
\hline 6 & 60 & Maize & 986 & 99 & 44 & 24 & 151 & 18.9 & 88.7 & 2 & - \\
\hline 6 & 61 & Barley & 971 & 132 & 22 & 37 & 189 & 18.3 & 85.7 & 2 & $4 *$ \\
\hline 6 & 64 & Wheat & 981 & 131 & 18 & 25 & 137 & 18.5 & 86.1 & 2 & 4 \\
\hline 6 & 641 & Wheat, pelleted & 968 & 157 & 22 & 28 & 134 & 18.5 & 90.1 & $2^{*}$ & - \\
\hline 6 & 607 & Peas & 970 & 263 & 10 & 65 & 166 & 18.8 & 87.4 & 2 & - \\
\hline 6 & 608 & Lupin seeds & 970 & 342 & 60 & 151 & 312 & 20.1 & 82.2 & 2 & 4 \\
\hline 7 & 62 & Wheat meal & 975 & 132 & 19 & 31 & 161 & 18.3 & 87.0 & 2 & $4^{*}$ \\
\hline 7 & 63 & Wheat bran & 944 & 180 & 42 & 90 & 400 & 19.1 & 69.5 & 2 & 4 \\
\hline 7 & 605 & Wheat middlings & 933 & 184 & 39 & 111 & 503 & 19.2 & 65.4 & 2 & $4^{*}$ \\
\hline 7 & 65 & Rice bran & 808 & 166 & 211 & 73 & 274 & 20.4 & 71.7 & 2 & - \\
\hline 7 & 601 & Maize meal & 909 & 158 & 52 & 71 & 254 & 18.0 & 80.4 & 2 & - \\
\hline 8 & 66 & Palm kernel expeller & 955 & 135 & 79 & 296 & 749 & 20.6 & 56.3 & 2 & - \\
\hline 8 & 661 & Palm kernel expeller & 955 & 148 & 91 & 239 & 735 & 20.7 & 69.6 & 2 & - \\
\hline 8 & 68 & Linseed expeller & 938 & 334 & 75 & 118 & 333 & 20.5 & 70.2 & 2 & - \\
\hline 8 & 603 & Coconut expeller & 933 & 215 & 120 & 161 & 538 & 20.2 & 83.3 & 2 & - \\
\hline 8 & 604 & Groundnut expeller & 935 & 556 & 83 & 61 & 131 & 20.9 & 88.8 & 2 & 4 \\
\hline 8 & 610 & Coconut oil meal & 933 & 228 & 86 & 152 & 467 & 19.7 & 82.1 & $2 *$ & - \\
\hline 8 & 602 & Soya bean oil meal & 937 & 451 & 20 & 112 & 246 & 19.5 & 84.7 & 2 & - \\
\hline 8 & 67 & Soya beans $70 / 30$ & 940 & 400 & 228 & 53 & 344 & 23.8 & 74.4 & 2 & - \\
\hline 8 & 671 & Soya beans $50 / 50^{2}$ & 935 & 365 & 193 & 56 & 172 & 22.7 & 81.1 & $2^{*}$ & - \\
\hline 8 & 672 & Soya beans $30 / 70^{2}$ & 935 & 365 & 188 & 54 & 158 & 22.6 & 84.5 & $2^{*}$ & - \\
\hline 9 & 69 & Maize gluten feed & 925 & 231 & 32 & 87 & 409 & 18.9 & 65.8 & 2 & - \\
\hline 9 & 691 & Maize gluten feed & 916 & 208 & 39 & 66 & 311 & 18.9 & 70.9 & $2^{*}$ & - \\
\hline 9 & 606 & Dried beet pulp & 882 & 107 & 6 & 138 & 301 & 16.3 & 79.0 & $2^{*}$ & - \\
\hline 10 & 21 & Compound feed & 914 & 206 & 53 & 115 & 331 & 18.5 & 79.8 & 4 & - \\
\hline 10 & 23 & Compound feed & 872 & 180 & 22 & 120 & 327 & 17.0 & 79.3 & 3 & 4 \\
\hline 10 & 24 & Compound feed & 912 & 167 & 38 & 109 & 310 & 18.1 & 81.0 & 4 & 4 \\
\hline 10 & 25 & Compound feed & 894 & 156 & 39 & 124 & 343 & 17.9 & 75.5 & 4 & - \\
\hline 10 & 26 & Compound feed & 917 & 92 & 26 & 207 & 465 & 17.9 & 60.6 & 4 & $4^{*}$ \\
\hline 10 & 27 & Compound feed & 916 & 205 & 45 & 75 & 254 & 18.5 & 80.9 & 4 & - \\
\hline
\end{tabular}


Table 2. Ingredients of the compound feeds tested ( $\mathrm{g} \mathrm{kg}^{-1}$ feed).

\begin{tabular}{lccccc}
\hline \multicolumn{2}{l}{ Compound feed } & & & \\
\cline { 2 - 6 } Ingredients & 21 & 23 & 24 & 25 & 27 \\
Oats & 125 & 200 & 125 & 150 & - \\
Maize & 75 & - & 75 & - & 168 \\
Wheat & - & - & - & 60 & - \\
Faba beans & 25 & - & - & - & - \\
Lupin seeds & - & - & - & - & 100 \\
Wheat bran & - & 150 & 54 & 108 & - \\
Rice bran & 24 & - & - & - & - \\
Maize gluten feed & 200 & 190 & 195 & 75 & 100 \\
Lucerne meal & 88 & - & 200 & 100 & - \\
Grass meal & - & 50 & - & - & - \\
Palm kernel expeller & - & 40 & - & - & - \\
Cotton seed expeller & - & - & - & 40 & 50 \\
Soya beans & 63 & - & - & - & 100 \\
Soya bean meal solv. extr. & - & 80 & - & - & - \\
Coconut expeller & 100 & - & 50 & 150 & - \\
Linseed expeller & 100 & 50 & 75 & 125 & 233 \\
Sugar beet pulp, dried & 100 & 50 & - & - & - \\
Manioc & - & 105 & 125 & 100 & 163 \\
Beet molasses & 75 & - & 75 & - & - \\
Cane molasses & - & 60 & - & 60 & 60 \\
\hline
\end{tabular}

first cut and wilted for 6 days. Hay 17 was actually grass seed straw. Dry matter content in wilted grass silage ranged from 44 to $67 \%$. The maize silage (Group 4) had a dry matter content of $30 \%$ and in fresh grass (Group 3) dry matter averaged $20 \%$. Dehydrated roughages (Group 5 - pressed big bales) were fed ground.

Cereals and pulses (Group 6) were fed as whole grains except for Feed 641, which was pelleted. The by-products of milling (Group 7) and the by-products of oilbearing seeds (Group 8) were fed in different physical forms. The feeds in Group 9 were regarded as miscellaneous and fed in pelleted form. Selection of the compound feed ingredients was based upon their importance to the production of compound feed for horses, on estimated energy value and on relative prices. The compound feeds were chosen from the feeds available on the market and were all pelleted. The main ingredients in these feeds are listed in Table 2. The composition of Feed 26 remains unknown.

\footnotetext{
Notes Table 1.

$1 \mathrm{OM}=$ organic matter, $\mathrm{CP}=$ crude protein, $\mathrm{CFAT}=$ crude fat, $\mathrm{CF}=$ crude fibre, $\mathrm{NDF}=$ neutral detergent fibre, $\mathrm{GE}=$ gross energy, $\mathrm{d}_{\mathrm{OMh}}=$ average $\mathrm{OM}$ digestibility in horses, $\mathrm{H}=$ number of horses per trial, $S=$ number of sheep per trial (numbers higher than 4 indicate repeated trial). Content of OM, CP, CFAT, CF and NDF in $\mathrm{g} \mathrm{kg}^{-1} \mathrm{DM}, \mathrm{GE}$ in $\mathrm{MJ} \mathrm{kg} \mathrm{kM}^{-1} \mathrm{DM}, \mathrm{d}_{\mathrm{OMh}}$ in $\%$.

2 Duplicate trials with different experimental feed/roughage ratio.

* Indicates between animal differences in excess of $3.0 \%$ units.
} 


\section{Results}

Both horses and wethers endured the experimental conditions without health or behavioural problems. Feed refusals were observed with horses fed sugar beet pulp. Dehydrated citrus pulp and faba beans were omitted to the digestibility trials because of high feed residuals in the preliminary palatability tests. Between animal differences remained within acceptable limits, both for horses and wethers.

\section{Digestibility}

Organic matter digestibilities as measured in horses are shown in Table 1. Figure 1 shows the average organic matter digestibility in horses $\left(\mathrm{d}_{\mathrm{OMh}}\right)$ of the feeds tested relative to crude fibre contents. As expected, the overall negative relationship be-

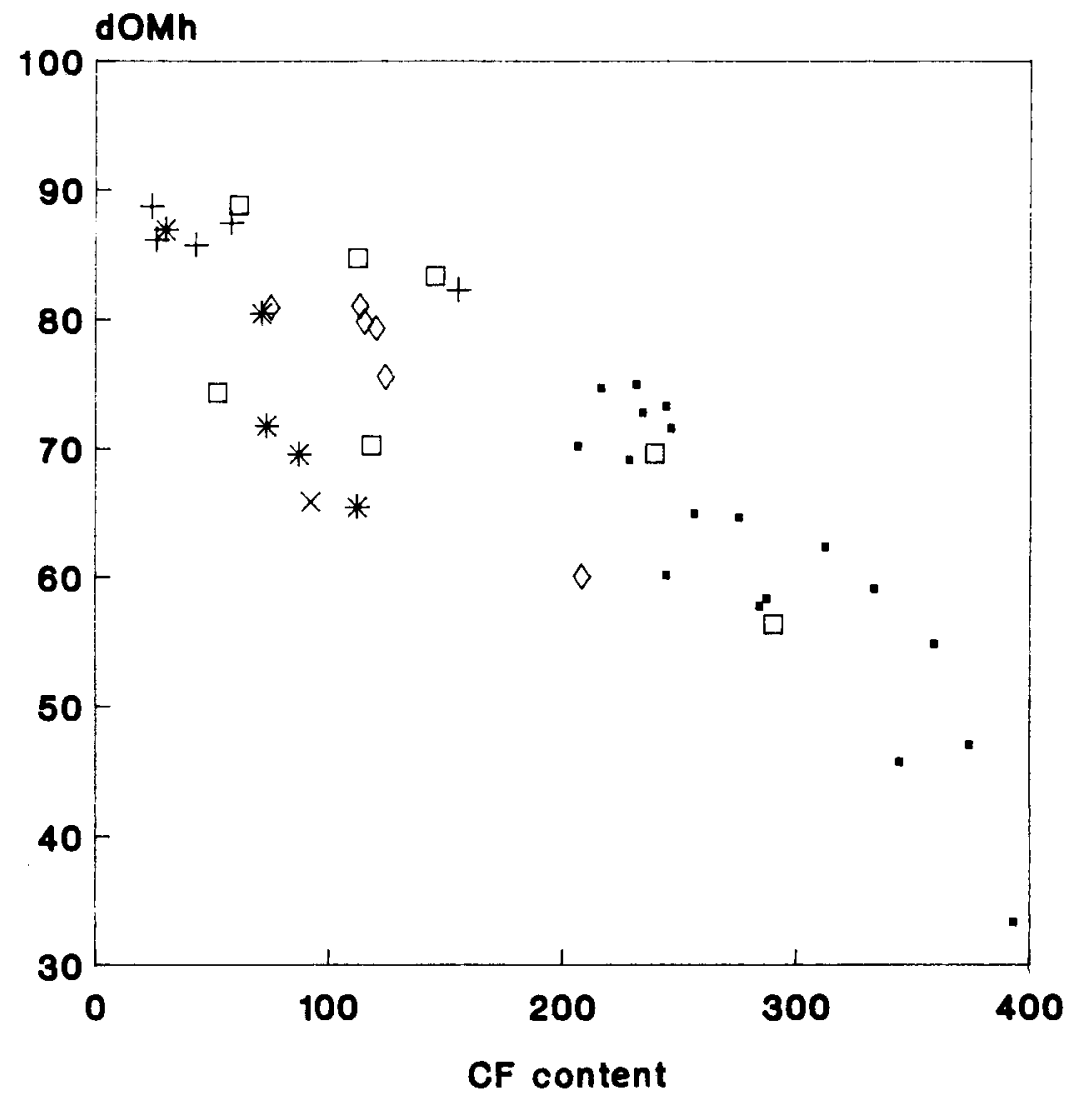

Fig. 1. Relationship between $d_{O M h}(\%)$ and CF content $\left(\mathrm{g} \mathrm{kg}^{-1} \mathrm{DM}\right)$ for different feedstuffs. $\square$ roughage, $\square$ oil by-products, + cereals, $\times$ maize gluten, $*$ milling, $\diamond$ compound feeds. 
tween crude fibre content and organic matter digestibility is evident. However, a clear difference exists in CF range between roughage and concentrates and linear relationships between $C F$ content and $\mathrm{d}_{\mathrm{OMh}}$ were different for roughage and concentrates. In most statistical analyses both types of feed were studied separately.

Table 3 displays the average organic matter digestibilities for roughages and for concentrates (compound feeds and compound feed ingredients) in horses and shows the results of comparisons with sheep $\left(\mathrm{d}_{\mathrm{OMs}}\right)$ and in vitro data $\left(\mathrm{d}_{\mathrm{O}}\right)$.

Organic matter digestibility of hay and fresh grass was found to be considerably lower in horses than in sheep, in particular because of a less intensive fibre digestion. Yet the difference observed in roughages between in vitro and in vivo (horses) was largest. Group 5 (dehydrated roughages) displayed appreciable variation. For concentrates the differences in OM digestibility between horses and sheep were smaller than for roughages. The single sample of maize gluten feed (Group 9) showed a large difference between in vivo and in vitro OM digestibility. Noteworthy is the fact that $\mathrm{d}_{\mathrm{OMh}}$ for the three compound feeds exceeded $\mathrm{d}_{\mathrm{OMs}}$ and yet compared favourably to $\mathrm{d}_{\mathrm{Ot}}$.

\section{Regression analyses}

A direct comparison of digestibility in horses and sheep was possible for 21 feeds. In Figure 2 the relationship between OM digestibility in horses and sheep is displayed. In general the OM digestibility was found to be lower in horses than in sheep

Table 3. Organic matter digestibility in horses $\left(\mathrm{d}_{\mathrm{OMh}}\right)$ compared with sheep $\left(\mathrm{d}_{O M s}\right)$ and in vitro digestibility $\left(\mathrm{d}_{\mathrm{O}}\right)$ data.

\begin{tabular}{|c|c|c|c|c|c|c|c|c|}
\hline \multirow[t]{2}{*}{ Group } & \multirow[t]{2}{*}{$n^{a}$} & \multirow[t]{2}{*}{$n^{b}$} & \multicolumn{2}{|l|}{$\mathrm{d}_{\mathrm{OMh}}$} & \multicolumn{2}{|c|}{$\mathrm{d}_{\mathrm{OMs}}-\mathrm{d}_{\mathrm{OMh}}$} & \multicolumn{2}{|c|}{$\mathrm{d}_{\mathrm{Ot}^{-}}-\mathrm{d}_{\mathrm{OMh}}$} \\
\hline & & & mean & $\mathrm{SD}$ & mean & $\mathrm{SD}$ & mean & $\mathrm{SD}$ \\
\hline \multicolumn{9}{|l|}{ Roughage } \\
\hline Grass hay & 7 & 6 & 54.0 & 11.0 & 8.1 & 1.5 & 10.7 & 2.8 \\
\hline Grass silage & 5 & 0 & 71.3 & 4.4 & - & - & 3.9 & 1.8 \\
\hline Fresh grass & 2 & 2 & 72.1 & 0.8 & 8.0 & 0.1 & 9.2 & 0.2 \\
\hline Dried roughage & 3 & 3 & 55.1 & 7.1 & 4.3 & 8.1 & 10.8 & 6.3 \\
\hline Maize silage & 1 & 0 & 70.1 & - & - & - & 1.7 & - \\
\hline \multicolumn{9}{|l|}{ Concentrates } \\
\hline Cereals + pulses & 5 & 3 & 86.0 & 2.4 & 4.1 & 5.9 & 1.3 & 2.1 \\
\hline Milling by-products & 5 & 3 & 74.8 & 8.8 & 2.0 & 4.1 & 1.8 & 2.2 \\
\hline Oil seed by-products & 7 & 1 & 75.3 & 11.2 & 1.0 & - & 1.8 & 6.1 \\
\hline Miscellaneous feeds & 1 & 0 & 65.8 & - & - & - & 17.8 & - \\
\hline Compound feeds & 6 & 3 & 76.2 & 7.9 & 3.6 & 1.4 & 0.8 & 0.9 \\
\hline
\end{tabular}

$\mathrm{n}^{\mathrm{a}}=$ number of horses - in vitro comparisons.

$\mathrm{n}^{\mathrm{b}}=$ number of horses - sheep comparisons. 


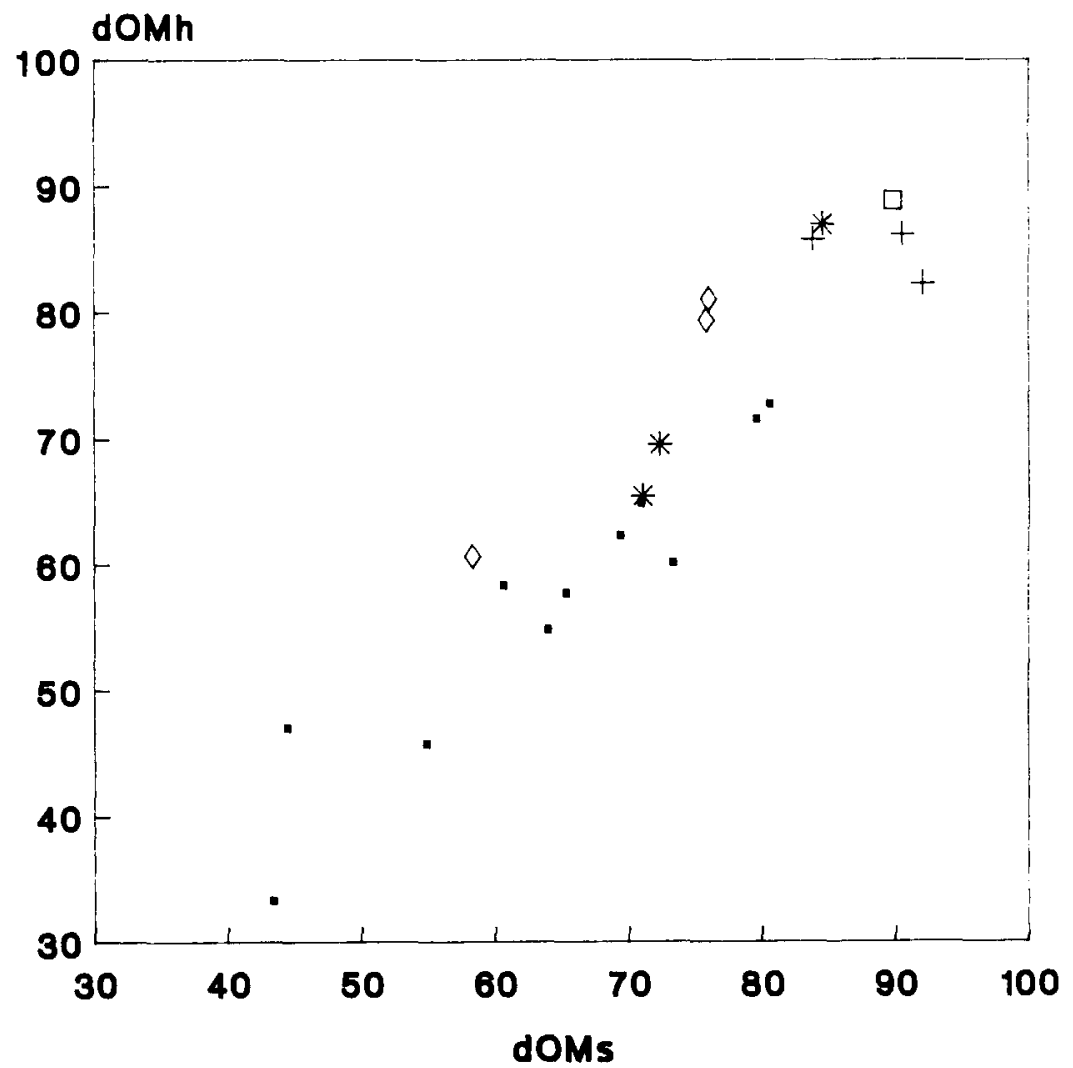

Fig. 2. Relationship between $\mathrm{d}_{O M h}(\%)$ and $\mathrm{d}_{\mathrm{OMs}}(\%)$ for different feedstuffs. $\square$ roughage, $\square$ oil byproducts, + cereals, $\times$ maize gluten, ${ }^{*}$ milling, $\diamond$ compound feeds.

for roughages and similar for concentrates. The single linear relationships for the different groups of feeds are given in Table 4 . The data show that the overall correlation of $\mathrm{d}_{O M h}$ to $\mathrm{d}_{\mathrm{OMs}}$ was satisfactory $(\mathrm{R}=0.936)$ but the $\mathrm{RSD}$ of the single linear relationship was too large to allow a reliable estimation of $d_{O M h}$ from $d_{O M s}$. Division into two main groups (roughages and concentrates) improved slightly the accuracy of prediction. For cereals no significant relationship could be calculated between $\mathrm{d}_{\mathrm{OMh}}$ and $\mathrm{d}_{\mathrm{OMs}}$.

Adding information of a feed's chemical composition in a multiple linear regression model improved the accuracy of prediction. Best fit multiple regression equations including $\mathrm{d}_{\mathrm{OMS}}$ and proximate analysis data are given in Table 5. Only those equations providing a significant improvement on single linear regression with $\mathrm{d}_{\mathrm{OMs}}$ are reported.

Results of single linear regression of $\mathrm{d}_{\mathrm{OMh}}$ on $\mathrm{d}_{\mathrm{Ot}}$ are shown in Table 6 . When considered as an alternative to $\mathrm{d}_{\mathrm{OMs}}$ comparison can be made with Table 4 . It 
should however be stressed that the number of samples was distinctly different.

Results of best fit combinations with $\mathrm{d}_{\mathrm{Ot}}$ and chemical components are given in Table 7. Information concerning the accuracy of estimations employing proximate analysis and NDF is displayed in Table 8.

Table 4. Univariate relationship in OM digestibility in horses $\left(\mathrm{d}_{\mathrm{OMh}}\right)$ related to sheep $\left(\mathrm{d}_{\mathrm{OM}}\right)$ for various feeds $\left(\mathrm{d}_{\mathrm{OMb}}=\mathrm{c}+\mathrm{b} \mathrm{d}_{\mathrm{OM}}\right)$.

\begin{tabular}{lrrlll}
\hline Group & $\mathrm{n}$ & $\mathrm{c}$ & $\mathrm{b}$ & $\mathrm{RSD}$ & $\mathrm{R}^{2}$ \\
All feeds & \multicolumn{1}{c}{$\mathrm{c}$} & -6.27 & 1.030 & 5.49 & 0.870 \\
Roughage & 11 & 1.19 & 0.871 & 4.03 & 0.880 \\
Grass hay & 6 & -15.74 & 1.124 & 0.83 & 0.995 \\
Dried roughage & 3 & 27.39 & 0.467 & 3.24 & 0.793 \\
Concentrates & 10 & 12.60 & 0.831 & 4.66 & 0.779 \\
Milling by-products & 3 & -43.10 & 1.541 & 1.46 & 0.984 \\
Compound feeds & 3 & -4.19 & 1.111 & 1.04 & 0.992 \\
\hline
\end{tabular}

Table 5. Best fit multiple regression equations for the calculation of $\mathrm{d}_{\mathrm{OMh}}$ from $\mathrm{d}_{\mathrm{OMs}}$ and proximate analysis data $\left(d_{O M h}=c+b_{1} d_{O M s}+b_{2} N D F+b_{3} C F\right)$.

\begin{tabular}{lrrlllll}
\hline Group & \multicolumn{1}{l}{$\mathrm{n}$} & $\mathrm{c}$ & $\begin{array}{l}\mathrm{b}_{1} \\
\left(\mathrm{~d}_{\mathrm{OMs}}\right)\end{array}$ & $\begin{array}{l}\mathrm{b}_{2} \\
(\mathrm{NDF})\end{array}$ & $\begin{array}{l}\mathrm{b}_{3} \\
(\mathrm{CF})\end{array}$ & $\mathrm{RSD}$ & $\mathrm{R}^{2}$ \\
All feeds & 21 & 39.61 & 0.626 & -0.039 & & 3.50 & 0.947 \\
Roughage & 11 & 28.50 & 0.732 & -0.032 & & 3.45 & 0.912 \\
Grass hay & 6 & -2.97 & 1.034 & & -0.022 & 0.51 & 0.998 \\
Concentrates & 10 & 65.70 & 0.336 & -0.048 & & 2.98 & 0.909 \\
\hline
\end{tabular}

Table 6. Univariate relationship in OM digestibility in horses $\left(\mathrm{d}_{\mathrm{OMh}}\right)$ related to in vitro digestibility $\left(\mathrm{d}_{O l}\right)$ for various feeds $\left(d_{O M h}=c+b d_{O}\right)$.

\begin{tabular}{lrrlll}
\hline Group & $\mathrm{n}$ & $\mathrm{c}$ & $\mathrm{b}$ & $\mathrm{RSD}$ & $\mathrm{R}^{2}$ \\
All feeds & \multicolumn{1}{c}{} & -14.9 & 1.135 & 5.41 & 0.819 \\
Roughage & 18 & -13.8 & 1.081 & 4.54 & 0.841 \\
Grass hay & 7 & -18.4 & 1.119 & 2.82 & 0.934 \\
Grass silage & 5 & -21.7 & 1.236 & 1.88 & 0.815 \\
Dried roughage & 3 & 20.2 & 0.530 & 0.75 & 0.989 \\
Concentrates & 24 & 4.3 & 0.920 & 4.85 & 0.727 \\
Milling by-products & 5 & -16.1 & 1.186 & 1.98 & 0.949 \\
Oil seed by-products & 7 & 9.4 & 0.856 & 6.49 & 0.665 \\
Compound feeds & 6 & 0.2 & 0.988 & 1.05 & 0.982 \\
\hline
\end{tabular}


Table 7. Best fit multiple regression equations for the calculation of $d_{O M h}$ from $d_{O I}$ and proximate analysis data $\left(d_{O M h}=c+b_{1} d_{O 1}+b_{2} C F+b_{3} N D F\right)$.

\begin{tabular}{lrllllll}
\hline Group & $\mathrm{n}$ & $\mathrm{c}$ & $\begin{array}{l}\mathrm{b}_{1} \\
\left(\mathrm{~d}_{\mathrm{O} 1}\right)\end{array}$ & \multicolumn{1}{l}{$\begin{array}{l}\mathrm{b}_{2} \\
(\mathrm{CF})\end{array}$} & $\begin{array}{l}\mathrm{b}_{3} \\
(\mathrm{NDF})\end{array}$ & $\mathrm{RSD}$ & $\mathrm{R}^{2}$ \\
All feeds & 42 & 19.3 & 0.784 & -0.043 & & 4.61 & 0.868 \\
Roughage & 18 & 28.4 & 0.806 & & -0.043 & 3.45 & 0.908 \\
Grass silage & 5 & 35.7 & 0.711 & & -0.038 & 0.37 & 0.993 \\
Concentrates & 24 & 24.1 & 0.740 & 0.048 & 0.032 & 4.31 & 0.784 \\
\hline
\end{tabular}

Table 8. Best fit regression equations for $d_{O M h}$ based on CF, NDF, CP, and CFAT $\left(d_{O M h}=c+b_{1} C F\right.$ $+b_{2} \mathrm{CP}+b_{3}$ CFAT $+b_{4}$ NDF).

\begin{tabular}{|c|c|c|c|c|c|c|c|c|}
\hline Group & $\mathrm{n}$ & c & $\begin{array}{l}\mathrm{b}_{1} \\
\text { (CF) }\end{array}$ & $\begin{array}{l}\mathrm{b}_{2} \\
\text { (CP) }\end{array}$ & $\begin{array}{l}\mathrm{b}_{3} \\
\text { (CFAT) }\end{array}$ & $\begin{array}{l}b_{4} \\
\text { (NDF) }\end{array}$ & RSD & $\mathrm{R}^{2}$ \\
\hline All feeds & 42 & 93.6 & -0.060 & & & -0.029 & 6.50 & 0.740 \\
\hline Roughage & 18 & 111.8 & -0.178 & & & & 5.04 & 0.803 \\
\hline Grass hay & 7 & 13.2 & & 0.272 & & & 4.65 & 0.821 \\
\hline Grass silage & 5 & 102.1 & & & & -0.066 & 1.87 & 0.819 \\
\hline Dried roughage & 3 & 177.2 & & & & -0.233 & 0.22 & 0.999 \\
\hline Concentrates & 24 & 91.9 & & & & -0.044 & 5.83 & 0.604 \\
\hline Cereals & 5 & 92.0 & & & & -0.033 & 1.37 & 0.678 \\
\hline Milling by-products & 5 & 138.3 & & -0.388 & & & 2.41 & 0.924 \\
\hline Oil seed by-products & 7 & 98.0 & -0.111 & & -0.067 & & 7.55 & 0.548 \\
\hline Compound feeds & 6 & 97.5 & -0.170 & & & & 2.93 & 0.863 \\
\hline
\end{tabular}

\section{Discussion}

\section{Procedure and data}

In this study the rations of the horses were restricted to fixed allowances of dry matter per kg liveweight. So the amount of available energy varied, depending upon gross energy concentration and digestibility. This standardization was chosen to lower the risk of differences in digestion due to differences in feeding level. MartinRosset \& Dulphy (1987), contrary to information concerning ruminants, could not demonstrate a significant influence of feeding level on digestibility in horses. In the French feed evaluation system for horses feeding level is still taken into account (Vermorel et al., 1984). It should be added, however, that it is exceptional to feed horses in excess of $2 \times \mathrm{M}$. So an eventual effect on digestibility, which could be attributable to feeding level, would be small.

According to Martin-Rosset et al. (1984), Henning \& von Gagern (1978) and Orton et al. (1985) the rather light work of the horses in our experiments is not expect- 
ed to significantly affect digestibility despite an increase in the passage of feed through the digestive tract.

\section{Digestibility}

Chenost \& Martin-Rosset (1985) reported for fresh grass an average difference of approximately $6.0 \%$ in OM digestibility between horses and sheep. This agrees favourably with our results. Our observations for OM digestibility of maize silage in horses agreed with results found by Martin-Rosset \& Dulphy (1987). The digestibility of nutrients in grass silage were higher than those reported by Coenen (1986) probably due to a lower crude fibre content. However, his results compare favourably with ours for grass hay.

The reasons for the higher OM digestibility in horses than in sheep for compound feeds remains unclear, as the effects of grinding and pelleting feeds does not seem to affect digestibility in horses to a large extent (Todd et al., 1983; Wolter et al., 1982; Hintz, 1985). The OM digestibility in compound feeds observed by Meyer et al. (1981) fit closely to our results when account is taken of differences in chemical composition.

\section{Prediction of $O M$ digestibility}

The digestibility of feedstuffs in horses may be approximated from tabulated values or prediction equations based upon a range of feed qualities tested in sheep trials. This information may be very useful to horse feed evaluation if a close relationship between sheep and horse data exists. As is evident from Table 4 the $\mathrm{d}_{\mathrm{OMs}}$ of hay can be confidently used to predict $d_{O M h}$. Martin-Rosset et al. (1984) found an equation to predict $d_{O M h}$ from sheep data for grass hay and straw which was very similar to ours: $\mathrm{d}_{\mathrm{OMh}}=-14.91+1.1544 \mathrm{~d}_{\mathrm{OMs}}$. The difference between their equation and ours ranges from 2.1 in feeds low in OM digestibility to 3.0 in highly digestible feeds. This difference may be explained by the sheep trials, as feeding level has a negative effect on OM digestibility. In our sheep trials the animals were fed at approximately maintenance, while in the French trials sheep were fed ad libitum. Application of the French equation (Chenost \& Martin-Rosset, 1985) for the fresh grass tested in our trials results in an overestimation of $2.5 \%$ units.

Experimental results confirm the inferiority of apparent $O M$ digestibility for roughages in horses compared to sheep or a well-calibrated in vitro digestibility determination. For long forage the overall relationship may be approximated using $\mathrm{d}_{\mathrm{OMh}}=1.1 \mathrm{~d}_{\mathrm{OMs}}$ (or $\mathrm{d}_{\mathrm{O}}$ ) $-\mathrm{c}$ (percentage units), where c equals 15,11 and 16 for grass hay, grass silage and fresh grass, respectively. The relationship proved inconsistent for artificially dried forage. For compound feed ingredients differences in the OM digestibility between horses and sheep or in vitro determinations varied considerably with on average lower results being obtained with horses. Subdivision of this feed category is necessary if acceptably accurate prediction of horse digestibility from sheep or in vitro data is to be obtained. Unfortunately, insufficient experimental data are available. 
Combination with chemical characteristics resulted in a more accurate prediction for some groups (Table 5). In particular NDF gave a significant improvement in a bivariate regression with $\mathrm{d}_{\mathrm{OMs}}$. Substitution of NDF with crude fibre provided a slightly inferior prediction. Subdivision of roughage and concentrate groups did not improve predictions based on $\mathrm{d}_{\mathrm{OMs}}$ and chemical characteristics. An exception to this was grass hay.

The RSD obtained in the equations predicting $d_{O M h}$ from $d_{O t}$ with all feeds and with roughages and concentrates separately were unsatisfactory (Table 6). Predictions for grass silage, milling by-products and compound feeds are satisfactory. Noticable is the similarity in regression coefficient and constant for all feeds, roughage, grass hay, grass silage and milling by-products. Cereals and pulses displayed a poor correlation between $\mathrm{d}_{\mathrm{OMh}}$ and $\mathrm{d}_{\mathrm{Ot}}(\mathrm{R}=0.5341)$.

Additional corrections for differences in fibre contents improved the prediction of $\mathrm{d}_{O M h}$ from $\mathrm{d}_{\mathrm{Ot}}$ for all feeds, for all roughages studied and for grass silages (Table 7). A marginal improvement was obtained in concentrates.

A direct prediction of digestibility or energy value from chemical characteristics is of course very interesting for practical application. Particularly with equations using similar chemical components for all kinds of feeds. Single and multiple regression resulted in the best fit predictions displayed in Table 8. Overall regressions were poor with expected negative relationships for $d_{O M h}$ with CF and NDF as was demonstrated by Martin-Rosset et al. (1984). For specific feed groups (except for oil by-products) the accuracy of prediction could be improved statistically but the number of samples available is far to small to advocate routine application of the equations derived. Substitution of NDF for CF provided a more reliable prediction for $\mathrm{d}_{\mathrm{OMh}}$ in concentrates, grass silage and dehydrated roughages. However prediction accuracy from chemical analysis alone was generally considered to be unsatisfactory.

\section{References}

Alvey, N. G., N. Galwey \& P. Lane, 1980. An introduction to Genstat. Academic Press, London, 152. pp.

Chenost, M. \& W. Martin-Rosset, 1985. Comparaison entre espèces (mouton, cheval, bovin) de la digestibilité et des quantité's ingérées des fourrages verts. Annales de Zootechnie 34: 291-312.

Coenen, M., 1986. Untersuchungen zur Verdaulichkeit von Pressschnitzel-, Gras- und Luzernesilage beim Pferd. Züchtungskunde 58: 383-391.

CVB, 1977. Data on nutritive value for ruminants and horses. In: Table on feedstuffs. Information about composition, digestibility and nutritive value. (In Dutch.) Centraal Veevoederbureau in Nederland, Lelystad.

Es, A. J. H. van, \& J. M. van der Meer, 1980. Chemical analysis for the prediction of nutritive value. 13th Annual Meeting of the European Association for Animal Production, Lelystad, p. 1-48.

Henning, A. \& W. von Gagern, 1978. Ernährung unf Fütterung. In Pferde, Nutzung, Züchtung, Fütterung, p. 509-559. VEB Deutches Landwitschaftsverlag, Berlin.

Hintz, H. F., J. K. Scott, T. Hernandez \& L Shewokis, 1985. Extruded feeds for horses. Proceedings of the Cornell Nutrition Conference, p. 81-85. Cornell University, Ithaca, New York.

Hoffmann, M., O. Steinhöfel \& R. Fuchs, 1987. Untersuchungen zur Verdaulichkeit de Rohnährstoffe bei Pferden. Archives of Animal Nutrition 37: 354-362. 
Martin-Rosset, W., J. Andrieu, M. Vermorel \& J. P. Dulphy, 1984. Valeur nutritive des aliments pour le cheval. In: Le cheval, Reproduction, selection, alimentation, exploitation, p. 209-203. Institut National de la Recherche Agronomique, Paris.

Martin-Rosset, W. \& J. P. Dulphy, 1987. Digestibility interactions between forages and concentrates in horses: Influence of feeding level - comparison with sheep. Livestock Production Science 17: 263-276.

Meyer, H., M. Schmidt \& V. Güldenhaupt, 1981. Untersuchungen über Mischfutter für Pferde, Deutches Tierärtztliche Wochenschrift 88: 2-5.

Orton, R. K., I. D. Hume \& R. A. Leng, 1985. Effects of level of dietary protein and exercise on growth rates of horses. Equine Veterinary Journal 17: 381-385.

Steg, A., S. F. Spoelstra, J. M. van der Meer \& V. A. Hindle, 1990. Digestibility of grass silage. Netherlands Journal of Agricultural Science 38: 407-422.

Todd, L., W. C. Sauer \& R. J. Coleman, 1983. Voluntary intake and nutrient digestibility in cubes, pellets, chopped or loose alfalfa for mature horses. Journal of Animal Science 57 (Suppl. 1): 273.

Udén, P. \& P. J. van Soest, 1982. Comparative digestion of timothy (Phleum pratense) fibre by ruminants, equines and rabbits. The British Journal of Nutrition 47: 267-272.

Vermorel, M., R. Jarrige \& W. Martin-Rosset, 1984. Métabolisme et besoins énergétique du cheval. Le système des UFC. In: Le cheval, Reproduction, selection, alimentation, exploitation, p. 239-276. Institut National de la Recherche Agronomique, Paris.

Wolter, R., J. P. Valette, A. Durix, J. C. Letourneau \& M. Carcelen, 1982. Digestibilité comparée de quatre céréales (avoine, orge, mais, blé) selon la mode de présentation, chez le poney. Annales de Zootechnie 31: 445-458. 